TUGAS PEMODELAN PROSES BISNIS

PENGENALAN PROSES BISNIS

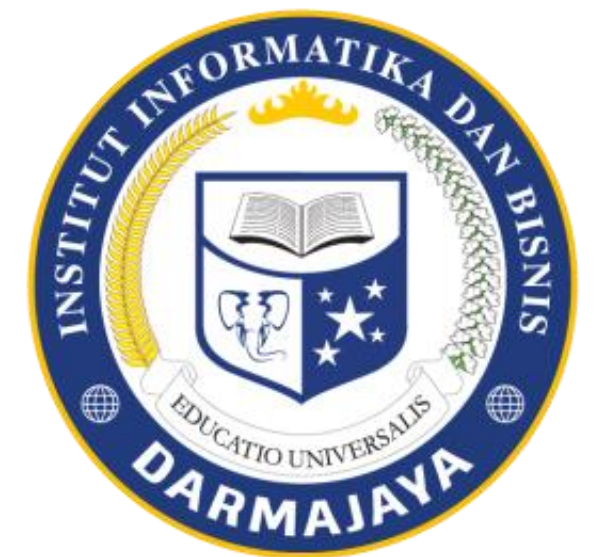

Disusun oleh :

MFIKRIKURNIAWAN (1711050019)

3SI-P2

\title{
INSTITUT INFORMATIKA DAN BISNIS
}

DARMAJAYA

SEMESTER GANJIL T.A 2018/2019 


\section{- ABSTRACT}

Bagian Isi Proses bisnis adalah kumpulan dari tugas atau aktivitas yang terstruktur yang dapat menghasilkan layanan atau produk tertentu untuk satu atau banyak konsumen [2]. Proses bisnis sering digambarkan secara visual dalam bentuk flowchart.

Karakteristik proses bisnis meliputi [8]:

- Definability, harus jelas batasan input dan outputnya.

- Order, harus terdiri atas sekumpulan aktivitas yang dilakukan dengan urut-urutan tertentu dan menempati ruang tertentu

- Customer, harus ada pihak yang menerima keluaran proses tersebut yaitu konsumen

- Value-adding, tranformasi yang terjadi di dalam proses harus memberikan nilai tambah bagi penerima.

- Embeddedness, proses tidak dapat berdiri sendiri, harus merupakan bagian terintegrasi dari organisasi

- Cross-functionality, proses biasanya melibatkan berbagai fungsional terkait dalam organisasi. Sebuah proses bisnis dapat diperbaiki melalui 4 area utama yaitu [8]:

- Efektivitas, merupakan ukuran kelayakan proses dan kemampuan proses untuk menghasilkan keluaran yang sesuai dengan harapan konsumen.

- Efisiensi, terkait dengan pengukuran kuantitatif, umumnya berupa waktu, yang diperlukan untuk menyelesaikan suatu produk/layanan.

- Kontrol Internal, scenario pengendalian pemanfaatan sumber daya internal organisasi, termasuk alokasi sumber daya untuk satu tugas/kegiatan.

- Kesesuaian dengan aturan dan kebijakan tertentu. 


\section{- ANALISIS PROSES BISNIS}

Analisis proses bisnis adalah aktivitas yang dilakukan untuk mengkaji proses bisnis yang sudah ada dan menerapkan berbagai ilmu praktis yang dapat membantu mengubah dan meningkatkan proses [2]. Tahapan pertama dalam melakukan analisis proses bisnis adalah memahami semua aktivitas di dalam proses. Pemahaman ini dapat dibantu dengan pemetaan proses atau pemodelan proses. Pemodelan struktur proses bisnis dapat dilakukan dengan berbagai pendekatan. Pendekatan yang paling umum adalah teknikal, struktur horizontal dan vertikal, dan ekstensi/intensif [5]. Struktur horizontal memudahkan penelusuran hubungan antara konsumen dan layanan yang digunakan. Struktur vertikal memberikan berbagai tingkat kedetilan yang beragam, dari tingkat teknikal hingga tingkat abstraksi. Pada model struktur ekstensif, proses digambarkan sebagai satu kesatuan. Sedangkan pada model struktur intensif, proses bisnis digambarkan sebagai interaksi berbagai entitas yang terdapat di dalam sistem. Model ini menggambarkan proses bisnis dari sudut pandang internal. Model proses intensif ini dapat dibagi lagi menjadi dua jenis yaitu [4]:

- Workflow oriented yang menggambarkan perilaku proses bisnis dari sudut pandang satu item yang melewati proses tersebut.

- Functional oriented yang menggambarkan perilaku unit fungsional / departemen dari sudut pandang urutan fungsi bisnis. 


\section{- WORKFLOW}

Proses workflow atau aliran kerja merupakan urut-urutan tahapan yang harus dilalui dalam memproses dokumen, pekerjaan atau informasi dalam sebuah organisasi. Contoh klasik workflow adalah aliran ban berjalan pada industri manufaktur [3]. Setiap tahapan pada proses workflow dapat dibagi menjadi 3 bagian utama yaitu input, proses dan output. Input merupakan masukan awal yang mengaktifkan (trigger) workflow tersebut, proses merupakan algoritma yang mengubah input menjadi output. Proses dapat dilakukan baik oleh manusia atau komputer. Output adalah informasi atau material yang dihasilkan workflow tersebut. Keluaran sebuah workflow kemudian diteruskan ke workflow lainnya pada sebuah sistem workflow organisasi yang besar. Cara kerja workflow yang terkomputerisasi sama seperti cara kerja workflow manual, kecuali keluaran workflow secara otomatis diteruskan ke tahapan berikutnya oleh komputer. Workflow terkomputerisasi ini biasanya digunakan untuk memproses dokumen di dalam organisasi. [8]. Workflow yang tidak efisien dan efektif seringkali menjadi sumber masalah pada organisasi. Masalah yang dapat ditimbulkan oleh workflow yang tidak tepat misalnya [4]:

- Ketidakseragaman penyelesaian masalah

- Informasi yang tidak konsisten

- Berulangnya sebagian proses, yang seharusnya tidak perlu terjadi.

- Tidak akuratnya keputusan yang diambil karena kesulitan penelusuran bukti pendukung keputusan. Oleh karena itu, memperbaiki workflow merupakan salah satu proses penting pada peningkatan kualitas proses bisnis secara keseluruhan, baik bagi individu maupun organisasi. Workflow yang sudah disempurnakan ternyata dapat mengoptimalkan efisiensi, meminimalisasi pemborosan waktu dan sumber daya, dan meningkatkan moral karena adanya obyektivitas penyelesaian masalah [6]. 


\section{- PERBAIKAN WORKFLOW}

Langkah-langkah yang dapat dilakukan dalam memperbaiki workflow meliputi [1]:

- Identifikasi dan eliminasi pemborosan, terutama pemborosan waktu.

- Membagi proses menjadi beberapa tahapan yang lebih kecil dan melakukan analisis tugas yang harus diselesaikan di setiap tahapan. Pada setiap tahapan harus ada satu fungsi yang bertanggung jawab untuk penyelesaian tugas dan mengeliminasi pelemparan tugas yang belum selesai ke bagian lain tanpa alur tanggung jawab yang jelas.

- Mengidentifikasi tahapan atau tugas mana yang dapat diotomasi. Ada bagian tertentu yang dapat diotomasi secara lengkap, atau sebagian. Tahapan perbaikan atau penyempurnaan workflow di atas harus dilakukan dengan tetap memperhatikan teknik manajemen tradisional dan aturan atau budaya yang berlaku di organisasi tersebut. Pendekatan yang dapat dilakukan dalam memperbaiki workflow sangat bergantung pada kasus proses bisnis yang dihadapi dan kondisi lingkungan proses bisnis tersebut. Beberapa hal yang dapat mempengaruhi teknik dan pendekatan ini misalnya [5]:

a.Pemahaman manajemen atas pentingnya perbaikan workflow

b.Kesadaran fungsional terkait yang memicu inisiatif perbaikan workflow Dukungan atau tersedianya fasilitas teknologi yang memadai untuk implementasi workflow baru (jika diperlukan). 


\section{- $\mathrm{CONTOH}$}

Divisi Diklat (Pendidikan dan Latihan) di sebuah institusi pemerintahan memegang peranan penting pada pengembangan sumber daya manusia. Melalui pengelolaan pendidikan dan pelatihan yang tepat maka sumber daya manusia di organisasi tersebut memiliki kesempatan mengembangkan potensinya dan diharapkan dapat memberikan kontribusi optimal bagi kemajuan organisasi. Divisi Diklat merupakan bagian terintegrasi dari fungsi manajemen kepegawaian. Untuk mendukung fungsional pengelolaan pendidikan dan pelatihan, divisi ini memerlukan sistem informasi yang diharapkan dapat membantu berbagai fungsi utama Diklat seperti menyebarkan informasi pelatihan, mengelola pendaftaran, mengalokasikan kelas serta membuat laporan hasil pelatihan kepada pihak manajemen. Analisis proses bisnis yang dilakukan untuk mengidentifikasi keadaan yang saat ini terjadi di lingkungan Diklat Departement X. Pendekatan yang dilakukan meliputi mempelajari skema prosedur yang sudah berjalan dan mewawancarai semua pihak yang terlibat dalam proses untuk mengetahui permasalahan. Pendekatan yang dilakukan dalam kasus perbaikan proses bisnis ini sangat sederhana, yaitu memetakan setiap permasalahan ke dalam 4 area peluang perbaikan yaitu [4]: Efektivitas (Ev), Efisiensi (Es), Internal control (IC) dan kesesuaian $(\mathrm{Cm})$. Kemudian untuk setiap area, dikaji peluang perbaikan prosesnya sesuai dengan kondisi dan kualitas tertentu yang ingin dicapai oleh unit organisasi terkait. Perbaikan ini dapat mengakibatkan perubahan baik berupa penambahan atau pengurangan proses atas aliran yang sudah berjalan. Saat ini, bagian Diklat Departemen $\mathrm{X}$ melakukan tugas dengan aliran kerja yang sangat sederhana yaitu menggunakan informasi satu arah berupa portal statis untuk menyampaikan informasi pelatihan, dan mengumumkan daftar peserta. Alur kerja yang terjadi dapat dilihat pada gambar 1 . Workflow pada gambar 1 menitikberatkan pada proses pendaftaran dan konfirmasi keikutsertaan pada sebuah program pelatihan/diklat. Tujuan utama proses tersebut adalah:

- Memberikan informasi pelatihan

- Memfasilitasi proses pendaftaran 
- Memberikan informasi konfirmasi peserta yang terdaftar.

Hasil analisis terhadap eksekusi proses bisnis di atas dan pemetaan beberapa permasalahan pada area seperti contoh yang tertera pada tabel 1. Dari hasil analisis terhadap proses bisnis yang sudah berjalan, terdapat tiga kondisi yang saat ini belum dapat dipenuhi yaitu :

1. Proses kontrol internal terhadap pelaksanaan program pelatihan yang sudah berjalan.

2. Kurangnya informasi yang mendukung proses pengambilan keputusan untuk menetapkan peserta program pelatihan.

3. Kurang lancarnya informasi dari berbagai stakeholder sehingga memperlambat proses pengambilan keputusan.

\section{- DAFTAR PERPUSTAKAAN}

18. Rangkuti, F(2007). Busines Plan.Teknik membuat Perencanaan Bisnis dan Analisis Kasus, Jakarta: PT Gramedia.

19. Vincent, G(1997). Statistical Process Control:Penerapan Teknik-Teknik Statistikal Dalam Manajemen Bisnis Total ,Jakarta: PT Gramedia 